\title{
Safety And Efficacy Of Proseal Laryngeal Mask Airway Versus Classic Laryngeal Mask Airway And Endo Tracheal Tube During Elective surgery
}

\author{
Soad A. Mansour, Wafaa G.Ahmed, Kawthar A. Azzam ,Tarek M. EL said \\ Department of Anaesthesia , Faculty Of Medicine For Girls-AL-Azhar University.
}

\begin{abstract}
The present study was performed to compare safety, efficacy of Proseal Laryngeal Mask Airway (PLMA), classic Laryngeal mask airway (LMA) and cuffed Endo Tracheal Tube (ETT) as a ventilatory device during controlled positive pressure ventilation and airway management, Haemodynamic response to insertion and removal, gastric tube insertion through either device, air leak detection and assessment of position by fiberoptic bronchoscope . Forty five ASA I or II patients aged between 18-55 years old, were divided equally into three groups of fifteen patients each, and airway management either through PLMA(groupI),classic LMA (groupII)and ETT (group III) . All patients were premedicated by zantac hydrochloride $150 \mathrm{mg}$ orally at mid night and two hours before the operation - Anaesthesia was induced with fentanyl $2 \mathrm{ug} / \mathrm{kg}$ and propofol $2.5 \mathrm{mg} / \mathrm{kg}$ and maintenance was with a mixture of $50 \% \mathrm{~N} 2 \mathrm{O}, 50 \% \mathrm{O} 2$ and isoflurane $1-1.5 \%$ and rocuronium $0.5 \mathrm{mg} / \mathrm{kg}$ followed by continous infusion of rocuronium $0.3-0.6 \mathrm{mg} / \mathrm{kg} / \mathrm{hr}$ A proper size PLMA, classic LMA or ETT was selected oxygenation and ventilation were optimal in $100 \%$ in group I and III while in group II $80 \%$ optimal and suboptimal in $13.3 \%$ and failed in $6.7 \%$. Haemodynamic parameters showed that significantly increase in HR and MAP in the three studied groups especially at insertion and removal of the airway device with statisticaly significant difference between group I,II in comparison to group III, comparison of gastric tube insertion showed that positive insertion was $86.7 \%$ in group I and in $46.7 \%$ in group II, while in group III positive insertion was $100 \%$ air leak was detected by epigastric auscultation which signified lower leakage in PLMA group than LMA group . Position assessment by fiberoptic bronchoscope in PLMA group was grade 4 in 5 patients, grade 3 in 5 patients, grade 2 in 4 patients and grade 1 in 1 patient while in LMA group it was grade 4 in 7 patients, grade 3 in 6 patients, grade 2 in 2 patients and grade 1 in no patient In conclusion :- PLMA and classic LMA could be better choices as ventilatory device in hypertensive and coronary artery disease patients .
\end{abstract}

\section{Introduction}

The Proseal Laryngeal Mask Airway (PLMA) is a new and advanced LMA airway that may be used for the same indication as the original classic (LMA))(1) . The (PLMA) was described by Brain in 2001. the airway tube is wire -reinforced, like aflexible (LMA), there is an additional drain tube placed laterally to the airway tube, the drain tube passes lateral then through the mask part of the device and exits at the distal tip of the Laryngeal cuff.(2)The drain tube is designed to allow insertion of gastric tube and to vent gas or liquid from the upper eosophagus. The
Laryngeal cuff of the (PLMA) is made of softer silicone than that of the classic (LMA) and covers the posterior aspect of the bowl of the mask, when inflated, this cuff presses the device forwards and is designed to improve the seal of the Larynx(1)The (PLMA) is a laryngeal mask device with a modified cuff and drainage tube forms a more effective seal than the classic (LMA) and isolates the respiratory tract from gastrointestinal tract when correctly positioned (3), Laparoscopic procedures are the most recent commonly performed general surgical procedures. 
Tracheal intubations is recommended for airway management to facilitate ventilation and prevent aspiration in laparoscopic procedures (4), the classic (LMA) and (PLMA) may be suitably alternatives but the PLMA is a more effective ventilatory device than the (LMA) (5).

The Aim of this study is to evaluate efficacy of Proseal Laryngeal Mask Airway to prevents aspiration of regurgitated fluids , during the laparoscopic procedures in comparison to LMA and Cuffed Endo tracheal tube.

\section{Patients and Methods}

This study was approved by our Anaesthesiology Department and informed consent was obtained from all patients Forty- five adult patients of both sexes , aged 18-55 years (ASA) IorII undergoing elective laparoscopic procedures were randomly allocated for airway management, with the PLMA airway, classic LMA or cuffed -ETT .Patients were excluded from the study if they have an incisor gap $<2.5 \mathrm{~cm}$, a body mass index $>35 \mathrm{~kg} / \mathrm{m} 2$ or at risk of aspiration (nonfasted, pregnant women or gastroesophageal reflux disease )Patients were divided randomly into three groups;

Group I :- fifteen patients were ventilated through PLMA

Group II :- fifteen patients were ventilated through classic (LMA)

Group III:- fifteen patients were ventilated through cuffed ETT

All patients were premedicated with Zantac hydrochloride $150 \mathrm{mg}$ orally at mid night and two hours before the operation. On arrival to the operating room, an intravenous cannula was introduced to all patients and $2 \mathrm{mg}$ midazolam I.V preinduction of anaesthesia was given routine monitoring of pulse oximetry and end -tidal $\mathrm{Co}_{2}$, blood pressure , electrocardiogram (ECG), were initiated. Anaesthesia was induced with fentanyl $2 \mathrm{ug} / \mathrm{kg}$ and propofol $2.5 \mathrm{mg} / \mathrm{kg}$. Maintenance was with a mixture of $50 \% \quad \mathrm{~N} 2 \mathrm{O}, 50 \% \quad \mathrm{O} 2$ and isoflurane $1-1.5 \%$ and rocuronium $0.5 \mathrm{mg} / \mathrm{kg}$ followed with continuous infusion of rocuronium $0.3-0.6 \mathrm{mg} / \mathrm{kg} / \mathrm{hr} \mathrm{A}$ size 4PLMA or classic LMA and size $7.5 \mathrm{~mm}$ cuffed ETT were used for female patients and size 5 PLMA or classic LMA and size 8.5 cuffed ETT were used for male patient in all groups . The PLMA and classic LMA intra cuff pressure were set at 30,40 $\mathrm{cmH} 2 \mathrm{O}$ (in size 4,5 respectively) in group I and II patients The ETT intra cuff pressure was set at $10 \mathrm{cmH} 2 \mathrm{O}$ in group III patients and controlled ventilation to was adjusted maintain $\mathrm{O} 2$ saturation $\geq 95 \%$ and end tidal $\mathrm{CO} 2$ between $(35-45) \mathrm{mm} \mathrm{Hg}$ :

Haemodynamic parameters including heart rate (HR), blood pressure and ECG was recorded $5 \mathrm{~min}$ before induction (base line ), $1 \mathrm{~min} 5 \mathrm{~min}$ and $30 \mathrm{~min}$ after insertion of the device and immediately after removal of the device.

- Insertion assessment :- by the number of insertion attempts required for proper position of the device $-\mathrm{A}$ failed insertion attempt was recorded and trachea was intubated conventionally

- Leak detection:- by epigastric auscultation

- Position assessment :- by fiberoptic bronchoscope in group I and II patients.

- ventilation and oxygenation assessment :by recording $\mathrm{O} 2$ saturation $\%$ and end tidal $\mathrm{CO} 2$ before and after carboperitoneum .

- Orogastric tube insertion - was tried in all patients in the three studied group .

- Aspiration detection by Litmes paper test . Once the group I and II patients awake the mask was removed and $\mathrm{PH}$ of the back and front of the PLMA or classic LMA was tested using Litmus paper sensitive to changes of $\mathrm{PH}$ at the end of surgery and anaesthesia was turned off and $100 \%$ oxygen was given to all patients, then the patient was asked to open his/her eyes . this was repeated until an appropriate response was obtained the PLMA or LMA was removed

\section{- Complications detection :-}

the incidence of vomiting breathholding, Laryngospasm, Loss of the airway maintenance or blood on removal of the device were recorded . The results were analyzed using $\mathrm{CHI}$ square, ANOVA and the students "t" 
tests. Data were represented as mean \pm SD and $\mathrm{p}<0.05$ was considered statistically significant .

\section{Results}

The demographic data of the patients are shown in table(1) there were no significant differences in age, body weight , height, as well as ASA classification between three groups. The duration of operation for group I patients ranged from 40-65 minutes With a mean value of $49.9 \pm$ 7.6 minutes, for group II patients, it ranged from 38-63 minutes with mean value of $50.7 \pm 7.3$ for group III patients ,It ranged from 36-62 minutes with a mean value of $47.7 \pm 7.9$ minutes, there was no significant differences between the three groups as regard the duration of operation table (2), insertion of PLMA in group I patients was successfull from 1st attempt in 12 patients (80\%), 2nd attempt in 2 patients $(13.4 \%)$ and 3rd attempt in I patient (6.6\%) .in group II patient, the LMA was successfully inserted from 1st attempt in 14 patients $(93.3 \%)$ and 2 nd attempt in 1 patient $(6.6 \%)$, while in group III patients ETT was successfully inserted in all patients from the 1st attempt there were no statistically significant differences between the three groups as regards the number of insertion attempts table (3) \& fig (1).

As regards position assessment using fiberoptic bronchoscope in group I \& II patients table (4) the PLMA fiberoptic position was grade 4 in 5 patients (33.4\%), in comparison to fiberoptic LMA position was grade 4 in 7 patients $(76.7 \%)$, grade 3 fiberoptic position was detected in 5 patients (33.4\%) in group I and in 6 patients (40\%) in group II .In group I , grade 2 fiberoptic position was detected in 4 patients $(26.7 \%)$ and in group II.it was detected in 2 patients (13.4\%), grade 1 fiberoptic position was detected in 1 patient $(6.7 \%)$ in group I and not detected in group II .

Ventilation and oxygenation after carboperitoneum table (5) ventilation and oxygenation were optimal in all patients of the three groups before carboperitoneum , remained optimal in all patients of group I and group II and group III , but in group II , it was optimal in 12 patients $(80 \%)$, suboptimal in 2 patients (13.3\%) and failed in 1 patient $(6.7 \%)$. ventilation and oxygenation was significantly lower in group II patients in comparison to that in group I and III patients.Air leak is detected by epigastric auscultation it's significantly lower in PLMA group than LMA group.

As regards heart rate (HR) table (6) and fig (2), showed no significant difference between all groups at the base lines. (HR) showed increase in all studied groups at one minutes after insertion of the device with a mean value of $76.67 \pm 9.08$ ' $78.10 \pm$ 9.05 and $84.53 \pm 11.64$ in group I, II and III respectively this increase in HR was statistically significant in all groups while five minutes after insertion of the device HR increased with a mean values of 75.43 $\pm 15.71,76.70 \pm 9.25$ and $76.80 \pm 10.46$ in PLMA, LMA and ETT respectively this increase in HR was statistically insignificant in group I while significant in other both groups, thirty minutes after insertion of the device HR changes also wer statistically insignificant in group I while HR in group II and group III showed statistically significant decrease with a mean values of $(72.77 \pm 8.71$ and $73.57 \pm$ 9.83 ) and in group II and III respectively. Immediately after removal of PLMA , LMA and ETT HR statistically significant increased in all studied groups with a mean value of $78.00 \pm 8.5112 .90 \& 78.83 \pm 8.42$ and $87.97 \pm 13.18$ in groups I'II and III respectively.

As regords Changes in Mean Arterial blood pressure (MAP) one minutes after insertion of the device. (table $7 \&$ fig 3 ) MAP increased statistically significant in all groups with a mean value of $101.43 \pm$ $5.99 ' 102.60 \pm$ b. 53 and $108.53 \pm 10.16$ $\mathrm{mmHg}$ in group I'II and III respectively . Five minutes after insertion of the device MAP decreased statistically significant with a mean values of $94.97 \pm 5.30$ ' $94.83 \pm$ 5.65 and $98.77 \pm 7.65 \mathrm{~mm} \mathrm{Hg}$ in group I' II and III respectively . thirty minutes after insertion of the device MAP decreased statistically significant in group I and II with a mean values of $90.77 \pm 5.36$ and 
$90.90 \pm 5.67 \mathrm{~mm} \mathrm{Hg}$ while in group III the decrease in MAP was statistically insignificant with a mean value of $95.47 \pm$ $6.94 \mathrm{~mm} \mathrm{Hg}$ Immediately after removal of PLMA or LMA and ETT MAP increased statistically significant with a mean value of $103.20 \pm 6.33 \cdot 104.50 \pm 6.40$ and $113.73 \pm$ $11.03 \mathrm{~mm} \mathrm{Hg}$ in group I'II and III respectively . ( Table $7 \&$ fig 3 )

* Gastric tube insertion in group I patients was successful in 13 patients $(86.7 \%)$. in group II patients it was successfully inserted in 7 patients $(46.7 \%)$. while in group III patients it was successfully inserted in all patients gastric tube insertion is significantly higher in group I and III than that in group II .

\section{* Litmus paper test :}

litmus paper test was positive in 1 patient (6.6) in group I and III and it was positive in 2 patients $(13.3 \%)$ in group II . there were no statistically significant differences between the three studied groups as regard litmus paper test .

* Postoperative complications : it was found that breath holding . bronchospasm , postoperative vomiting and sore throat were more common in group III patients and blood on the surface of the PLMA group was common than other two groups

Table (1) Demographic data in the three studied groups . mean \pm SD

\begin{tabular}{|c|c|c|c|c|c|}
\hline Group variable & I & II & III & F & P \\
& $\mathrm{n}=15$ & $\mathrm{n}=15$ & $\mathrm{n}=15$ & Test & Test \\
\hline Age (years) & $35.07 \pm 9.52$ & $33.23 \pm 10.20$ & $34.93 \pm 11.83$ & 0.28 & 0.76 \\
Range & $20-53$ & $18-55$ & $18-55$ & & \\
& & & & \\
Weight $(\mathrm{Kg})$ & $75.37 \pm 6.93$ & $74.23 \pm 8.38$ & $74.80 \pm 9.53$ & 0.14 & 0.87 \\
& $63-90$ & $59-90$ & $60-90$ & & \\
\hline
\end{tabular}

significant if $\mathrm{p}<0.05$

Table (2)Duration of operation in the three studied groups . mean \pm SD

\begin{tabular}{|c|c|c|c|c|c|}
\hline $\begin{array}{c}\text { Group } \\
\text { data }\end{array}$ & $\begin{array}{c}\text { GI } \\
\mathbf{n = 1 5}\end{array}$ & $\begin{array}{c}\text { GII } \\
\mathbf{n = 1 5}\end{array}$ & $\begin{array}{c}\text { GIII } \\
\mathbf{n = 1 5}\end{array}$ & F & P \\
\hline $\begin{array}{c}\text { Duration } \\
\text { (min) } \\
\text { range }\end{array}$ & $49.9 \pm 7.6$ & $50.7 \pm 7.3$ & $47.7 \pm 7.9$ & 0.67 & 0.57 \\
\hline
\end{tabular}

Table (3) Comparison of number of insertion attempts of the device between three studied groups . mean \pm SD

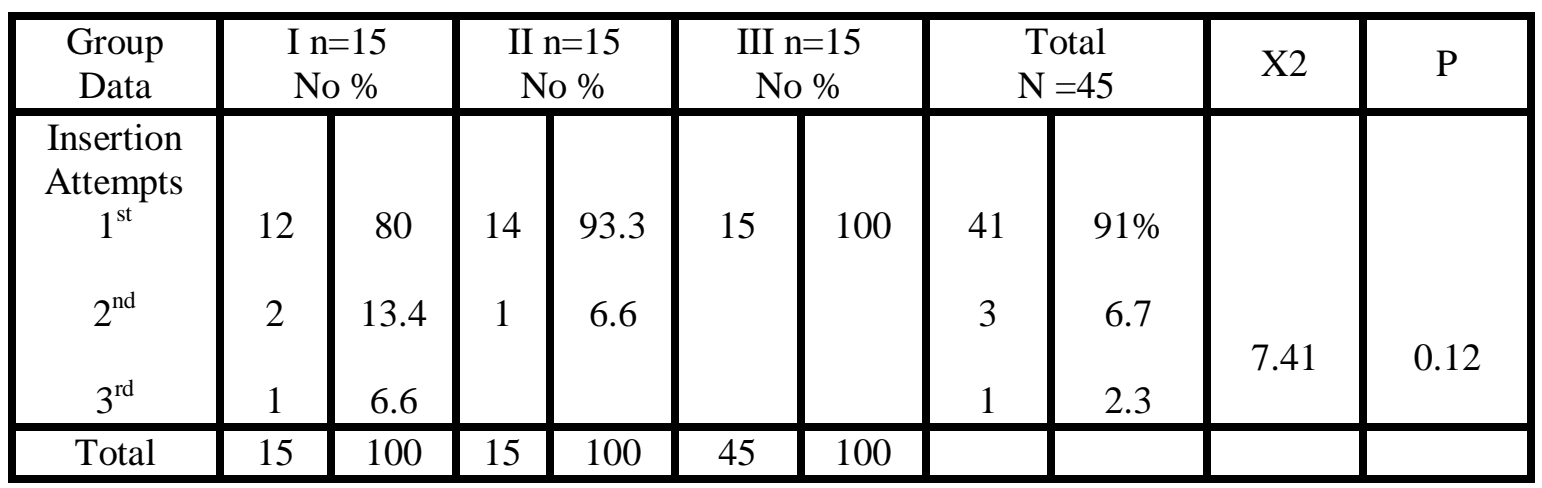

$\mathrm{X} 2$ is significant if $\mathrm{p}<0.05$ 


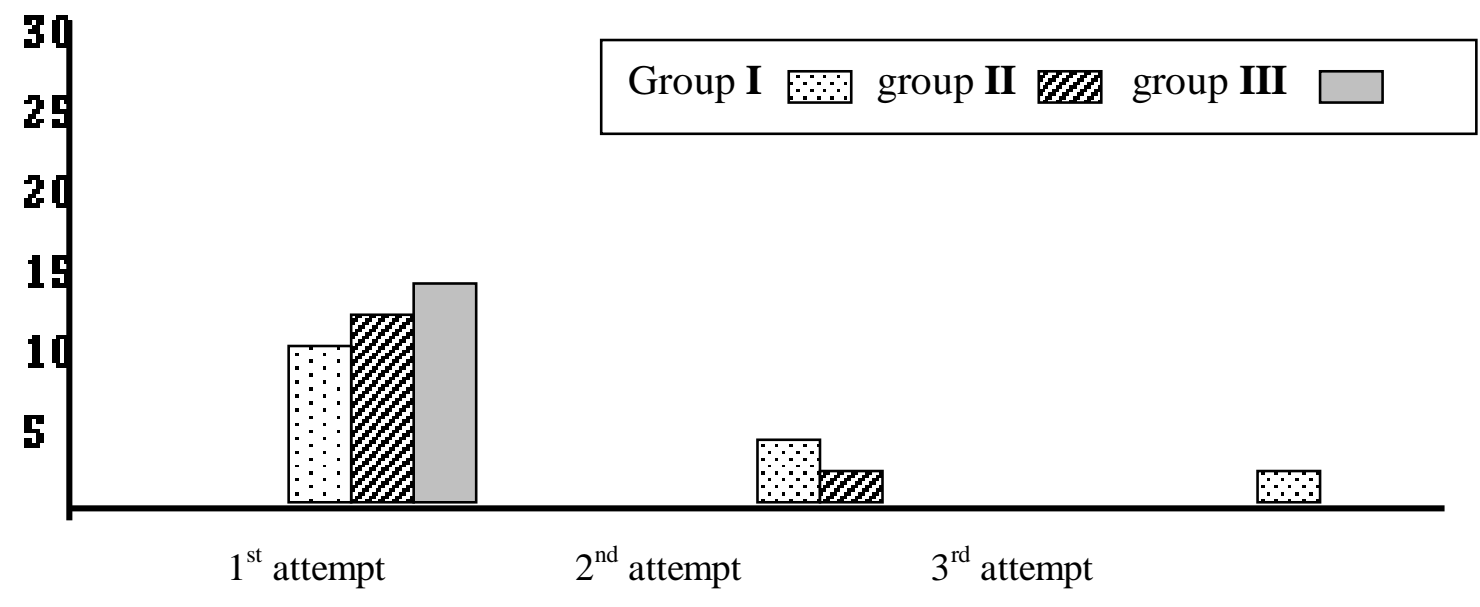

Table (4) Position assessment using fiber-optic bronchoscope in group I\&II

\begin{tabular}{|c|c|c|c|c|c|c|c|c|}
\hline \multirow{2}{*}{$\begin{array}{c}\text { Group } \\
\text { data }\end{array}$} & \multicolumn{2}{|c|}{ Group I } & \multicolumn{2}{|c|}{ Group II } & \multicolumn{2}{|c|}{ Total } & \multirow{2}{*}{$\mathrm{X} 2$} & \multirow[b]{2}{*}{$\mathrm{p}$} \\
\hline & $\mathrm{Nc}$ & & & & & $\%$ & & \\
\hline Position & & & & & & & & \\
\hline urade & & & & & & & & \\
\hline 1 & 1 & $6.7 \%$ & 0 & & 1 & $3.3 \%$ & & \\
\hline 2 & 4 & $26.7 \%$ & 2 & 13.3 & 6 & $20 \%$ & & \\
\hline 3 & 5 & $33.4 \%$ & 6 & $40 \%$ & 11 & $36.7 \%$ & & \\
\hline 4 & 5 & $33.4 \%$ & 7 & $76.7 \%$ & 12 & $40 \%$ & 1.37 & 0.71 \\
\hline Total & 15 & 100 & 15 & 100 & 30 & 100 & & \\
\hline
\end{tabular}

Table(5) Comparison of ventilation and oxygenation after carbo peritoneum between the three studied groups

\begin{tabular}{|c|c|c|c|c|c|c|c|c|c|c|}
\hline \multirow{2}{*}{$\begin{array}{l}\text { Group } \\
\text { data }\end{array}$} & \multicolumn{2}{|c|}{$\underset{n=15}{\text { Group I }}$} & \multicolumn{2}{|c|}{ Group II $n=15$} & \multicolumn{2}{|c|}{$\begin{array}{c}\text { Group III } \\
\mathrm{N} 0=15\end{array}$} & \multicolumn{2}{|c|}{$\begin{array}{l}\text { Total } \\
\mathrm{N}=45\end{array}$} & & \\
\hline & N 0 & $\%$ & & & N0 & $\%$ & N0 & $\%$ & & \\
\hline $\begin{array}{c}\text { Ventilation } \\
\& \text { oxygenation }\end{array}$ & & & & & & & & & & \\
\hline Optimal & 15 & 100 & 12 & $80 \%$ & 15 & 100 & 42 & $93.3 \%$ & & \\
\hline Suboptimal & & & 2 & $13.3 \%$ & & & 2 & $4.4 \%$ & 12.86 & 0.01 \\
\hline failed & & & 1 & $6.7 \%$ & & & 1 & $2.2 \%$ & & \\
\hline
\end{tabular}


Table (6) Changes in heart rate (beats/min) in three studied groups mean \pm SD

\begin{tabular}{|c|c|c|c|c|c|c|c|c|c|}
\hline Time & $\begin{array}{c}\text { Group } \\
\text { mean } \pm S D\end{array}$ & $\begin{array}{l}\text { paired } t \\
\text { test }\end{array}$ & $\mathrm{p}$ & $\begin{array}{c}\text { Group } \\
\text { mean } \pm S D\end{array}$ & $\begin{array}{c}\text { paired } t \\
\text { test }\end{array}$ & $\mathrm{p}$ & $\begin{array}{c}\text { Group } \\
\text { mean } \pm \text { SD }\end{array}$ & $\begin{array}{l}\text { paired } t \\
\text { test }\end{array}$ & $\mathrm{p}$ \\
\hline $\begin{array}{c}5 \text { minutes } \\
\text { before induction }\end{array}$ & $73.60 \pm 9.25$ & - & - & $74.10 \pm 9.03$ & - & - & $74.83 \pm 8.58$ & - & - \\
\hline $\begin{array}{l}1 \text { min after } \\
\text { insertion }\end{array}$ & $76.67 \pm 9.08$ & 20.29 & 0.79 & $78.10 \pm 9.05$ & 23.13 & $<0.001$ & $84.53 \pm 11.64$ & 10.06 & $<0.001$ \\
\hline $\begin{array}{l}5 \text { minutes after } \\
\text { insertion }\end{array}$ & $75.43 \pm 15.71$ & 0.79 & 0.432 & $76.70 \pm 9.25$ & 5.86 & $<0.001$ & $76.80 \pm 10.46$ & 2.69 & 0.012 \\
\hline $\begin{array}{l}30 \text { minutes } \\
\text { after insertion }\end{array}$ & $72.97 \pm 8.85$ & 1.33 & 0.194 & $72.77 \pm 8.71$ & 3.01 & 0.005 & $73.57 \pm 9.83$ & 2.07 & 0.047 \\
\hline $\begin{array}{l}\text { immediately } \\
\text { after removal }\end{array}$ & $78.00 \pm 8.51$ & 12.90 & $<0.001$ & $78.83 \pm 8.42$ & 12.86 & $<0.001$ & $87.97 \pm 13.18$ & 11.57 & $<0.001$ \\
\hline
\end{tabular}

Fig (2)Heart rate ( beats / minute )

$\rightarrow$ group I $\rightarrow$ group II $\rightarrow$ group III

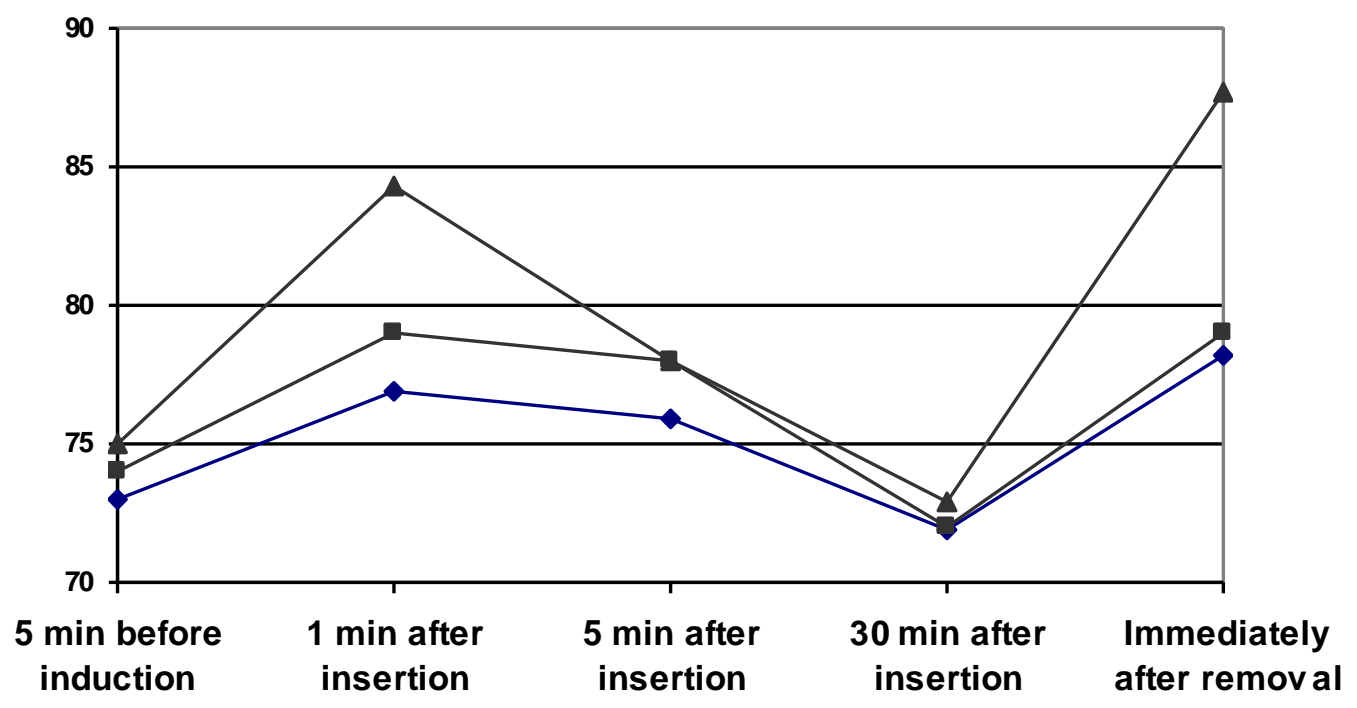


Table (7) Changes in mean arterial blood pressure (MAP) mean \pm SD paired $t$ test in three studied groups

\begin{tabular}{|c|c|c|c|c|c|c|c|c|c|}
\hline Time & $\begin{array}{c}\text { Group I } \\
\text { mean } \pm \text { SD }\end{array}$ & $\begin{array}{c}\text { Paired } \\
\text { T test }\end{array}$ & $\mathrm{p}$ & $\begin{array}{c}\text { Group II } \\
\text { Mean } \pm \text { SD }\end{array}$ & $\begin{array}{c}\text { Paired } \\
\text { T test }\end{array}$ & $\mathrm{p}$ & Group III & $\begin{array}{c}\text { Paired } \\
\text { T test }\end{array}$ & $\mathrm{p}$ \\
\hline $\begin{array}{c}5 \text { min before } \\
\text { induction }\end{array}$ & $97.13 \pm 5.96$ & - & - & $98.10 \pm 6.16$ & - & - & $96.47 \pm 6.67$ & - & - \\
$\begin{array}{c}1 \text { min after } \\
\text { insertion }\end{array}$ & $101.43 \pm 5.99$ & 10.944 & $<0.001$ & $102.60 \pm 6.53$ & 15.482 & $<0.001$ & $108.53 \pm 10.16$ & 11.904 & $<0.001$ \\
$\begin{array}{c}5 \text { min after } \\
\text { insertion } \\
30 \text { min after } \\
\text { insertion }\end{array}$ & $94.97 \pm 5.30$ & 4.540 & $<0.001$ & $94.83 \pm 5.65$ & 8.521 & $<0.001$ & $98.77 \pm 7.65$ & 3.425 & 0.002 \\
\hline $\begin{array}{c}\text { immediately } \\
\text { after removal }\end{array}$ & $103.20 \pm 6.33$ & 13.649 & $<0.001$ & $104.50 \pm 6.40$ & 17.588 & $<0.001$ & $113.73 \pm 11.03$ & 14.203 & $<0.001$ \\
\hline
\end{tabular}

Fig (3)Mean arterial blood pressure ( $\mathrm{mm} \mathrm{Hg})$

$\rightarrow$ group I $\rightarrow$ group II $\leftarrow$ group III

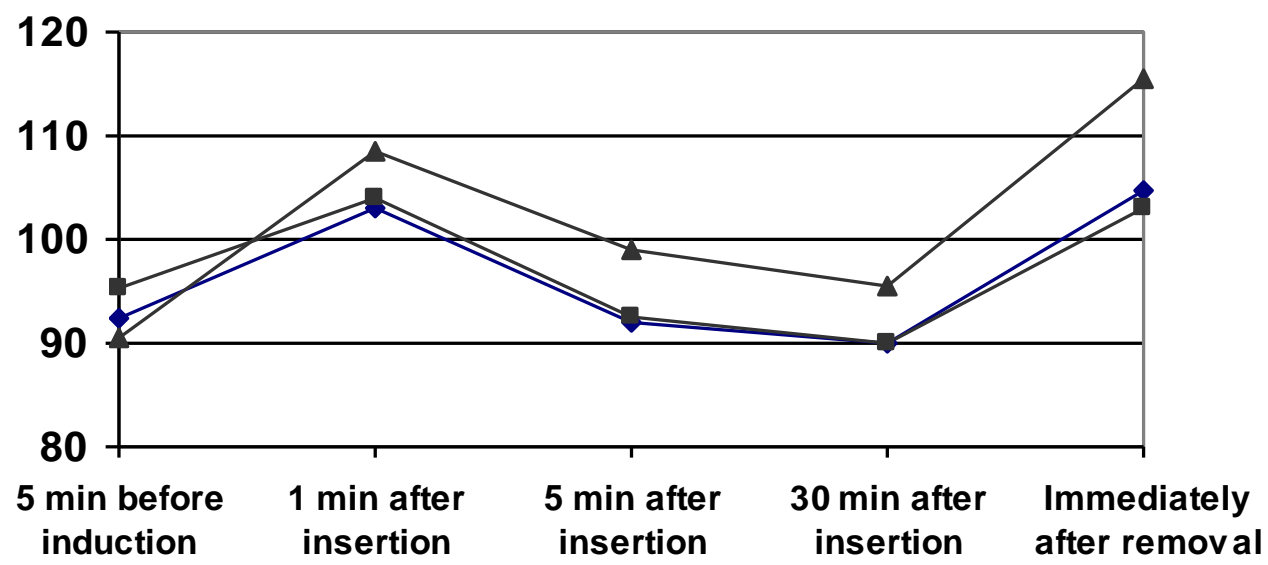

\section{Discussion}

The PLMA is a new, advanced LMA that may be used for the same indication as the original classic LMA, the PLMA is specifically designed to provide additional benefits which may extend the range of procedures for which the LMA is indicated. In addition to the features and benefits to the classic LMA, PLMA may offer the added protection provided by an esophageal drain tube (6), laparoscopic procedures are the most recent commonly performed general surgical procedures (7), the classic LMA and PLMA may be suitable as alternative to $\operatorname{ETT}(8)$, the goal of the 
present study was to evaluate the safety and efficacy of the new airway device (PLMA), during positive pressure ventilation in comparison to the classic LMA and ETT. Also to study the incidence of complications during the use of the three airway devices, and in the postoperative period. The current study demonstrated that the heart rate was increased significantly in the three studied groups especially after insertion and removal of the device ( $t$ vaule $=0.79 \cdot 5.86$ and 2.69) after insertion in group I 'II and III respectively and $p<0.001$ after removal of the airway device in three studied groups due to sympathetic reflex stimulation of mechanical and chemical stimuli mediated by the superior laryngeal nerve (5) these results are in agreement with the results reported by Hartley et al; (10) who found that insertion of the LMA is associated with only a $0-20 \%$ rise in HR this was more pronounced by Dyson et al; (11) who demonstrated that increase of $20 \%$ or more of HR following extubation in normotensive patients . The present study results go hand to hand with the study done by Swann et al; (12) as they reported that the tracheal tube group had significantly greater heart rates at 5 minutes after induction but there was no differences there after . also the present study are in agreement with the study done by Imai et al; (13) as they reported that LMA insertion produces less haemodynamic stress response than fiber optic guided orotracheal intubation .

As regard mean arterial blood pressure (MAP) changes it shown that it increased significantly in the three studied groups especially after insertion and removal of the device $(\mathrm{p}<0.001)$ due to catecholamine release. These results were in agreement with that previously done by Hartley et al; (10) who reported that tracheal intubation as well as extubation, causes tachy- cardia and hypertension. The present study found that MAP changes during insertion and removal of the ETT (group III) patients was significantly higher than PLMA and LMA group I and II respectively. These results were in agreement with the study of Hickey et al; (14) and Evans et al; (6) they found that
LMA insertion is associated with only $20 \%$ rise in blood pressure this can be related to avoidance and lack of instrumentation of the larynx .

As regords number of insertion attempts it was found that insertion of the airway device was successful from $1^{\text {st }}$ attempt in $80 \%$ ' $93.3 \%$ and $100 \%$ group I 'II and III respectively. This means that, the insertion of PLMA was difficult than LMA and ETT because PLMA is larger and bulkier than the classic LMA and more mouth opening is needed (2) . Brimacombe et al;(15) found that the LMA -classic is easier and quicker to insert than LMAP . $1^{\text {st }}$ attempt insertion success rate (LMA 91\% and PLMA 82\%) $2^{\text {nd }}$ attempt insertion success rates (LMA 7\% and PLMA 14\%), but after 3 attempts success rates were similar . Suggesting that both are clinically effective airway device. In agreement with the present study the studies done by Cook et al; (2) .Maltby et al; (16) who revealed that these were no failures in placement of either LMA or ETT and no cross overs between groups . In contrast with the results of the present study. Brimacombe et al; (17), Who reported that the PLMA was as easy to insert as LMA with the introducer.

In this study, air leak was detected during mechanical ventilation by epigastric auscultation, Air leak is significantly lower in PLMA group than LMA group most probably because the PLMA forms a better seal by the larger ventral cuff plugs gaps in the proximal pharynx and the dorsal cuff pushes the ventral cuff more firmly into the epiglottic tissues (17)These result agree with cook et al; (2) and Evans et al; (6) who showed that positive pressure ventilation was entirely successful with no audible gas leak in more patients using PLMA than LMA. While Brimacombe et al; (18) on the other hand concluded that audible oropharyngeal leaks were not detected with either device at $8 \mathrm{ml} / \mathrm{kg}$ tidal volume but were commonly detected with LMA at $12 \mathrm{ml} / \mathrm{kg}$ (TV) . the absence of air leak was probably due to low tidal volume and proper size selection of the airway device . Fiber-optic bronchoscope was used for assessment of the device position was grade 4 in $33.4 \%$ and $76.7 \%$ in group I and II respectively 
,grade 3 fiber-optic position was detected in $33.4 \%$ in PLMA and $40 \%$ in LMA patients, while grade 2 fiberoptic was detected in $26.7 \%$ in group I and $13.4 \%$ in group II ' grade 1 detected in $6.7 \%$ in group I and $0 \%$ in group II this means that the fiberoptic score was higher for LMA than PLMA because these was less epiglottic down folding and is probably caused by the broader proximal cuff catching the epiglottis during insertion (18), this was supported by Brimacombe et al; (15) who demonstrated that fiber- optic determined anatomic position better with LMA, the present results were relatively close to that done by keller et al; (19) who found that the fiber-optic position is better with LMA than PLMA . Ventilation and oxygenation were optimal in all patients of the three groups before carboperitoneum . After carboperitoneum it remained optimal in all patients of group I and III but in group II it was optimal in 12 patients (80\%) suboptimal in 2 patients $(13.3 \%)$ and failed in 1 patient (6.7\%) this indicates that PLMA and ETT are more effective ventilatory device than the LMA in the patients undergoing laparoscopic surgery . In agreement of these results, Lu et al; (20) and Cook et al; (2) they reported that the PLMA provides a more reliable airway than the classic LMA for positive pressure ventilation . A non agreement study to the present results done by Maltby et al; (16) who concluded that correctly placed LMA of appropriate size may be safe and effective alternative to an ETT for PPV. In contrast to the present study , maltby et al; (21) who confirmed that ppv assessed by end tidal co2 is equally satisfactory,through the LMA/PLMA or ETT during gynac-ologic laparoscopy .This difference with our result is due to absence of upper abdominal laparoscopic procedures in their study. As regard gastric tube insertion it was found that it was successful in 13 patients $(86.7 \%)$ in group I and in 7 patients $(46.7 \%)$ in group II while in group III patients it was successfully inserted in all patients . this shows that gastric tube insert-ion was comparable between the PLMA and ETT and was statistically lower in LMA group $<0.001$. Our data are in line with Brimacombe et al; (15) and Brain et al; (1) they found that the nasogastric tube insertion through the drainage tube of the PLMA more successful in contradiction $\mathrm{Lu}$ et al; (20) they found that gastric tube was successful in all patients with the PLMA placement this may be due to appropriate lubrication, selection of appropriate size of the orogastric tube and low incidence of folding over of the drainage tube.

Regurgitation and Aspiration detection by litmus paper test once the group I and II patients awake the mask was removed and $\mathrm{PH}$ of the back and front of the PLMA or classic LMA was tested using litmus paper sensitive to changes of $\mathrm{PH}$. Litmus paper test was detected in two patients (13.3\%) in group II and in one patient in group I and group III (6.6\%) . This mean that the PLMA is an effective as ETT in protection of the respiratory tract from aspiration of the gastric contents but LMA is not as safe as PLMA and ETT in airway protection against aspiration (17) these results goes hand to hand with the previous results reported by Evans et al; (22) and Akhtar et al; (23) they reported that PLMA is likely to provide better protection of the airway from passive regurgitation than either no air way protection device or the classic LMA .On the other hand, Swann et al; (12) reported that these was no clinically detectable incidents of regurgitation of gastric contents occurred in the LMA or ETT groups . Because they excluded patients at high risk of gastric reflux . Also Maroof et al; (24) described that most cases of regurgitation have one or more predisposing factors including emergency anaesthesia, obesity, previous gastric surgery, elective upper abdominal surgery, trendelenburg position with intra - abdominal insufflation, and airway difficulties .

\section{As regards postoperative complic-} ations :

It was found that breath holding, bronchospasm, postoperative vomiting and sore throat were more common in group III patients and blood on the surface of the PLMA group was more common than on the two groups . in this results the incidence of sore throat in PLMA group was noted in $13.3 \%$ (2 patients), after operation (in 
recovery area) and in 20\% (3 patients) after 24 hours of surgery. This was statistically similar to that of the LMA group and lower than that of the ETT, in agreement of these results Evans et al; (6) ' Brimaconbe et al; (15) they reported that the incidence of postoperative sore throat was similar in the PLMA and LMA group of patients. In the present study the incidence of blood detection on the surface of the PLMA was $20 \%$ of patients which was significantly higher than the other two groups which was $6.6 \%$ of patients in the LMA and ETT groups. This indicates that the frequency of trauma would be reduced with increasing experience of the PLMA use (20). In agreement of the present results $\mathrm{Lu}$ et al; (20) Brain et al; (1) and Cook et al; (2) they found that after device removal there were few complications with either device .

\section{Conclusion}

Proseal Laryngeal Mask Airway (PLMA) is not designed to be a replacament for the tracheal tube, but it offers several advantages over the classic LMA, as drainage tube which provide better protection of regurgitation than the classic LMA and facilitates easier and quicker orogastric tube placement . A double cuff arrangement mask ( PLMA) is more effective ventilatory device during carboperitoneum in laparoscopic procedures .

\section{References}

1- Brain AIJ, Verghese C, strube PJ,. the LMA 'proseal'-a laryngeal mask with an oesophageal vent. $\mathrm{Br} \mathrm{J}$ anaesth; 2000 84:650-654

2- Cook $\mathbf{T}$, Nolan $\mathbf{J}$, verghese $\mathbf{C}$. Randomized cross over comparison of the proseal with the classic laryngeal mask airway in unparalysed anaesthet-ized patients. Br J anaesth 2002;88:527-33

3- Brimacombe J, Berry A. The incidence of aspiration associated with laryngeal mask airway -a meta analysis of published literature. J clin Anesth 1995; 7:297-305.

4- Cunningham AJ, Brull SJ. Laparoscopic cholecystectomy : anesthetic implications . Anesth Analg 1993;76:1120-33 .
5- Brimacombe J, Lu PP, Yang C. proseal versus classic laryngeal mask airway for positive pressure ventilation during laparoscopic cholecystectomy $\mathrm{Br} \mathrm{J}$ Anaesth 2002;6:824-7

6- Evans N, Gradner S,James M. The proseal laryngeal mask: results of a descriptive trial with experience of 300 cases. Br J anaesth 2002;88:534-539.

7- Cunningham AJ, Brull SJ. Laparoscopic cholecystectomy : anesthetic implications . Anesth Analg 1993;76:1120-33 .

8- Brimacombe J, Kller C. Airway protection with the proSeal laryngeal mask airway. Anaeth Intesive care 2001;29(3):288-91

9- Sant' Ambrogio G, Mathew OP, Fisher JT . Laryngeal receptors responding to transmural pressure, airflow and local muscle activity .Resp physiol 1983;54:371330 .

10- Hartley M, Vaughan RS . problems associated with tracheal extubation. $\mathrm{Br} \mathbf{J}$ Anaesth 1993;71:561-568 .

11- Dyson A, Isaac PA, and Pennant JH. Esmolol attenuates cardiovascular responses to extubation.Anesth Analg 1990; 7: 675-678 .

12- Swann DG, Spens H, and Edwards S. Anesthesia for gynaecological laparoscopy - a comparison between the laryngeal mask airway and tracheal intubation. Anaesthesia 1993;48:431-434.

13- Imai M, Matsumura C,and Hanaoka Y, Kemmotsu O. Comparison of cardiovascular responses to airway management : fiberoptic intubation using a new adapter, laryngeal mask insertion, or conventional laryngoscopic intubation. J Clin Anesth 1995; 7: 14-18.

14- Hickey S, Cameron AE, Asbury AJ. Cardiovascular response of insertion of Brain's of laryngeal mask Anesthesia 1990;45:629-633.

15- Brimacombe J, Keller C, Fullerkrug B. A multicentre Study Comparing the ProsealTM and ClassicTM Laryngeal Mask Airway in Anesthetized, Nonparalysed patients. Anesthesiology 2002;96:289-295.

16- Maltby JR, Beriault MT, Watson NC. Gastric distension and ventilation during laparoscopic cholecystectomy: LMAClassic vs. tracheal intubation. Can J Anaesth 2000;47:622-626.

17- Brimacombe J, and Keller C. ProSeal laryngeal mask airway . A randomized cross over study with the standard laryngeal 
mask airway in paralyzed, anestheized patients . Anesthesiology 2000;93:104-109.

18- Brimacombe J, Keller C, and Boehler $\mathbf{M}$ positive pressure ventilation with the ProSeal versus classic laryngeal mask airway: a randomized, cross over study of healthy female patients. Anesth Analg 2001;93: 1351-1353.

19- Keller C, and Brimacobe J. Mucosal pressure and oropharyngeal leak pressure with the ProSeal versus the laryngeal mask airway in anesthetized paralysed patients. Br J Anaesth 2000;85:262-266.

20- Lu pp, Brimacombe J, and Yang C. proSeal versus classic laryngeal mask airway for positive pressure ventilation during laparoscopic cholecystectomy. $\mathrm{Br}$ J Anaesth 2002;88(6):824-827.
21- Maltby JR, Beriault MT, and Watson NC. LMA-Classic TM and LMAproSeal $^{\mathrm{TM}}$ are effective alternatives to endotracheal intubation for gynecologic laparoscopy. Can J Anaesth 2003;50:7177

22- Evans N, Garden S, and James $M$. proseal laryngeal mask protects against aspiration of fluid in the pharynx. $\mathrm{Br} \mathrm{J}$ Anaesth 2002;88:584-587.

23- Akhtar TM, Street MK. Risk of aspiration with the laryngeal mask airway. Br J Anaesth 1994;72:447-450.

24- Maroof M, khan RM, Siddique MS. Intraoperative aspiration pneumonitis and the laryngeal mask airway. Anesth Analg 1993;77:409-410. 


\section{أمان وفاعلية القتاع الحنجري الحافظ للممرات الهوائية مقارنة بالقناع الحنجري العادي والأنبوب الرغامي ذو البالون أثناء الجراحات الاختيارية}

\section{سعاد أحمد منصور، وفاء جابر احم، كوثر عبد الرحمن عزام، طارق محمد السعيد

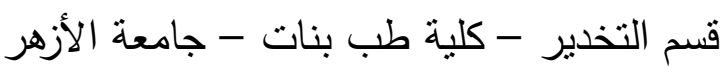

القناع الحنجري الحافظ للممرات الهوائية هو قناع حنجري جديد ومنطور يستخدم في نفس استخدامات القناع الحنجري العادي لكنه صمم لكي يضيف مميزات أخرى ويوسع مجال استخدام القناع الحنجري.

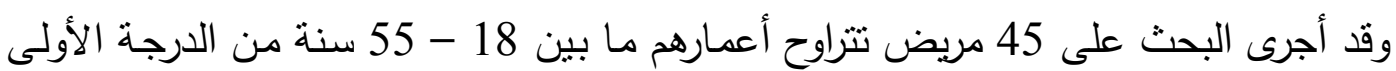

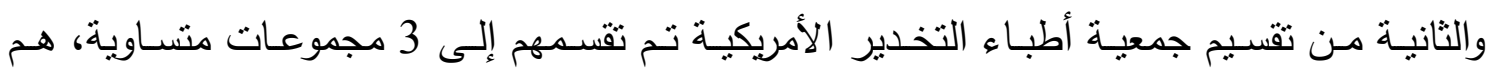

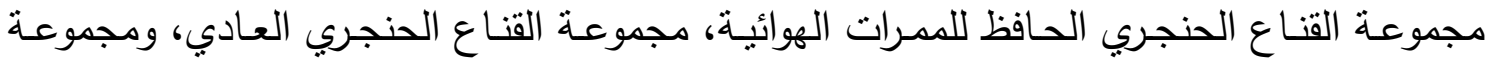

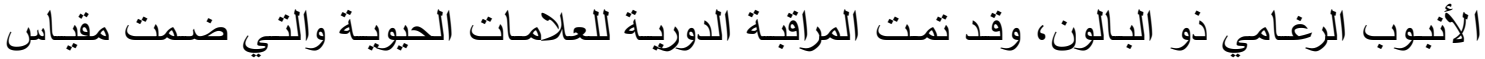

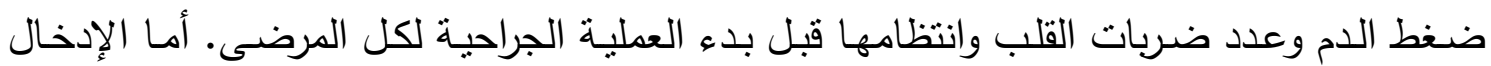
التخديري فتم باستخدام 2 ميكروجرام/كجم من عقار الفنتانيل و 2.5 مجم/كجم من عقار البروبوفول

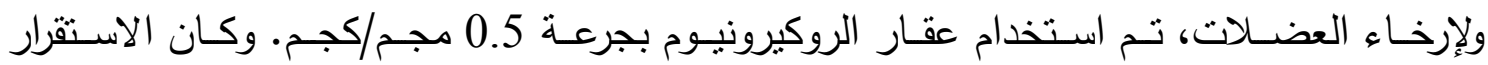

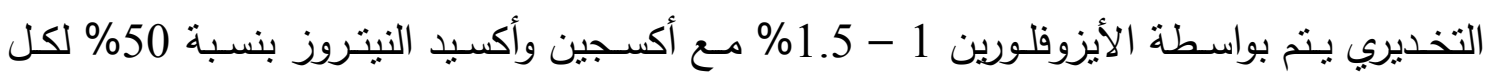

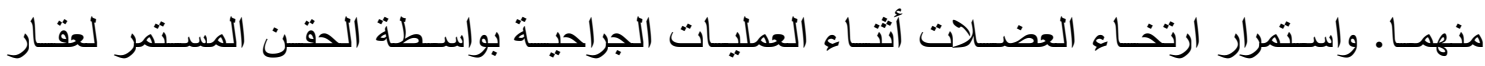
الروكيرونيوم بجرعة 0.3 - 0.6\% مجم/كجم/ساعة للدحافظة على استجابة التتبيه العصبي بنسبة التهاء

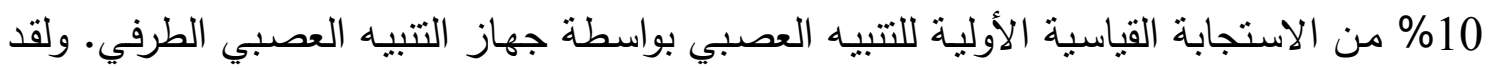

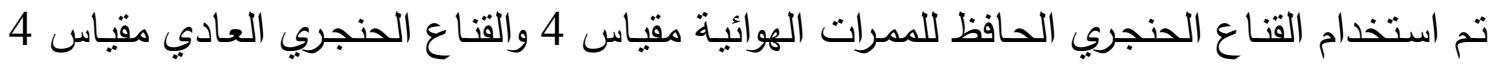

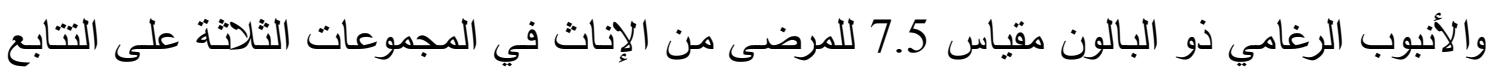

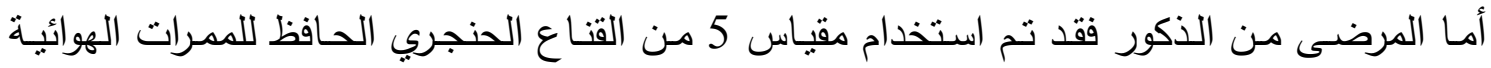
ومقياس 5 من القناع الحنجرى العـادى ومقياس 8.5 من الأنبوب الرغامي للمجموعات الثنات الثلاثتة

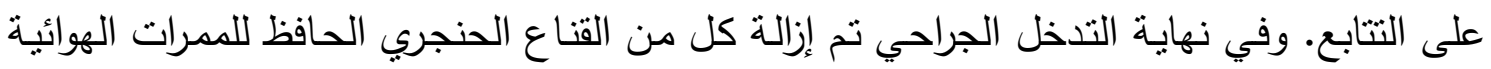

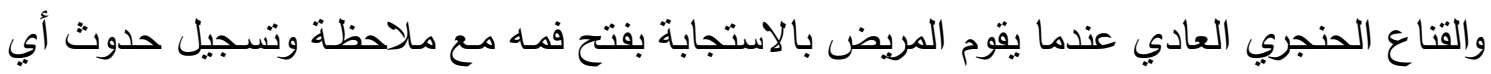
مضاعفات أثناء فترة الإفاقة. وقا أخذت القياسات التالية: 1 - قياس التغيرات في ديناميكية الدورة الدموية وتتشمل معدل النبض وانتظامه ومتوسط الضغط الثرياني وذك قبل مرحلة الإدخال التخديري بخمس دقائق وبعد مرور دقيقةتثم خمسة دقائق 
ثم ثلاثين دقيقة من الادخال التخديرى ، ثم مباشرة بعد إزالة القناع الحنجري الحافظ للممرات

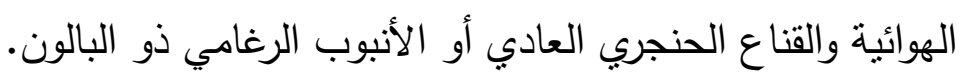

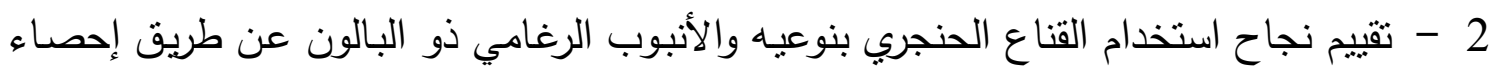

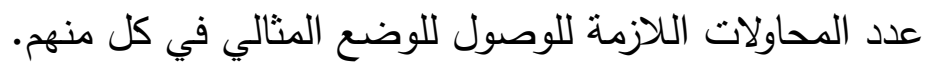

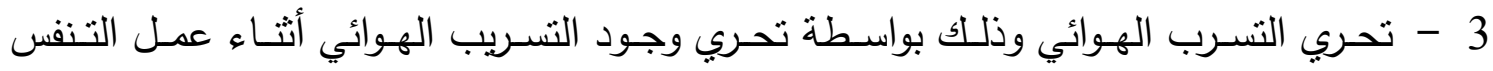
الصناعي للمرضى. تصني 4 - تقييم وضع القناع الحنجري عن طريق استخدام المنظار الرغامي ذو الألياف الضوئية في المجموعنين الأولى والثنانية. 5 - قياس ضغط إغلاق الممرات الهوائية.

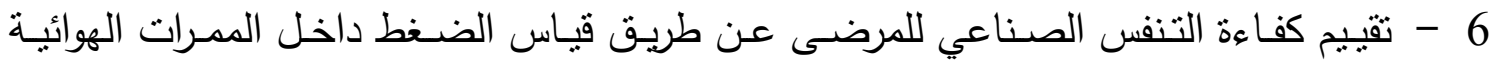

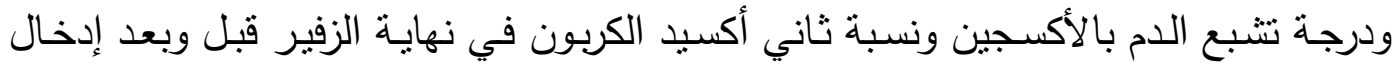

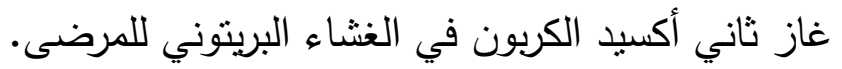

$$
\begin{aligned}
& 7 \\
& 8 \text { - تحري استتشاق السوائل المرتجعة مع الجهاز الهضئ الهيمي. }
\end{aligned}
$$

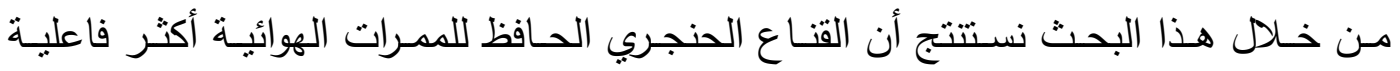

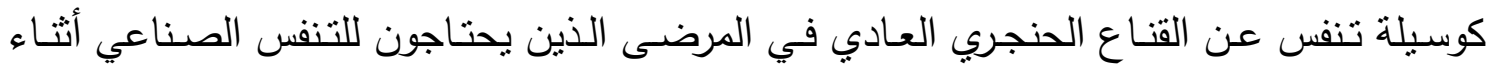

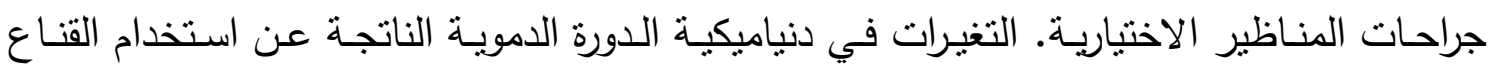

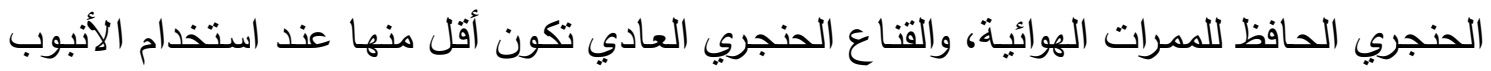

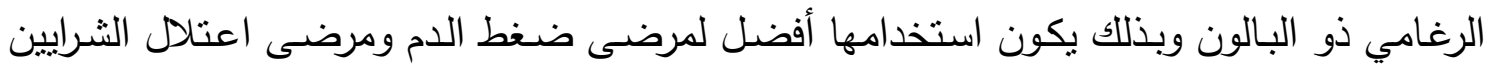

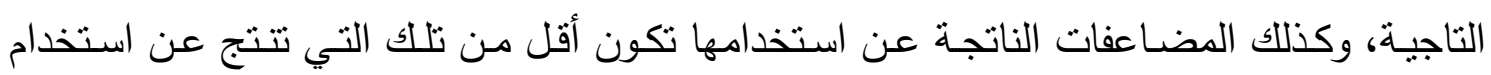

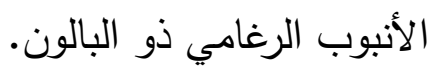

